\title{
Evaluation of Internet websites about floaters and light flashes in patient education
}

\author{
A valiação da informação dos pacientes sobre \\ miopsias e fotopsias através da Internet
}

\author{
Andréa Lima Barbosa ${ }^{1}$ \\ Elisabeth Nogueira Martins ${ }^{2}$
}

Trabalho realizado no Departamento de Oftalmologia da Universidade Federal de São Paulo - UNIFESP - São Paulo (SP) - Brazil.

${ }^{1}$ Post-Graduate Researcher of Emergency Section of the Department of Ophthalmology - Universidade Federal de São Paulo - UNIFESP - São Paulo (SP) - Brazil.

${ }^{2}$ Head of the Ocular Trauma - Emergency Section of the Department of Ophthalmology - Universidade Federal de São Paulo - UNIFESP - São Paulo (SP) - Brazil.

Correspondence to: Andréa Lima Barbosa. Rua Djalma Ribeiro, 25 - Bloco II - Apto. 1701 - Rio de Janeiro (RJ) CEP 22790-790

E-mail: andrealimabarbosa@ig.com.br

Recebido para publicação em 01.06.2006

Última versão recebida em 22.05.2007

Aprovação em 31.05.2007

\begin{tabular}{l} 
ABSTRACT \\
\hline Purpose: Flashes of light and floaters are most commonly caused by \\
posterior vitreous separation but may be associated with sight-threatening \\
disorders. Prevention of severe sequelae requires prompt dilated eye \\
examination. Thus, information dissemination is crucial. This study \\
aimed to evaluate the quality of information about floaters and light \\
flashes available for patients on the Internet. Methods: Cross-sectional \\
study. In July 2005 we evaluated information available on the Internet \\
regarding floaters and light flashes, using two search engines (MetaCrawler \\
and MSN) and three key terms ("floaters", "dark spots eye", and "light \\
flashes eye"). The quality of each website was evaluated using a score \\
system. The sites were classified as academic, organizational or com- \\
mercial. Readability, general quality of the website (based on: ownership, \\
purpose, authorship, author qualification, attribution, interactivity, and \\
currency) and quality of the specific content (definition, causes, epide- \\
miology, diagnosis, treatment, and prognosis) were analyzed. Results: \\
Of 145 websites evaluated, 49 were included. Four sites ( $8.2 \%$ ) were \\
academic, 9 (18.4\%) organizational, and 36 (73.4\%) commercial. In the \\
majority of the sites (53.0\%) information was poor and quality was not \\
correlated with website classification. Conclusions: Information about \\
floaters and light flashes available on the Internet is poor.
\end{tabular}

Keywords: Vitreous detachment/etiology; Vision disorders/etiology; Internet; Information systems; Patient education

\section{INTRODUCTION}

Internet has become a widely available source of medical information. Websites about diseases and treatments are increasing ${ }^{(1)}$. Providing adequate information through simple texts can be a powerful tool in patient education. Awareness of key symptoms can trigger a prompt medical evaluation which is beneficial to many disorders. However, quality of online information is not uniform ${ }^{(2-4)}$ and patients are often unable to critically judge what is available.

Floaters are defined as shapes seen drifting across the vision with variable shapes and sizes. The flashing light consists of a dim white or golden arc of light, usually in the temporal periphery, that is often related to retinal traction during vitreous separation or the impingement of the vitreous body onto the retina during eye movement. Light flashes or floaters should alert the clinician because they can be an initial sign of sight-threatening diseases ${ }^{(5)}$ (e.g., uveitis, retinal detachment, diabetic, and hypertensive retinopathy with hemorrhage). 
The purpose of the present study is to evaluate the quality of information on floaters and light flashes available in the Internet.

\section{METHODS}

\section{Site selection}

We attempted to mimic patients' Internet search using the keywords "floaters", "light flashes eye", and "dark spots eye" to select the sites from two search engines, MSN (www.msn. com) and MetaCrawler (www.metacrawler.com). The evaluation of these sites was performed on July 2005. MetaCrawler integrates the results from different search engines including Google, Alta Vista, Ask Jeeves, About, Looksmart, Teoma (DirectHit), Overture, Find What, and Yahoo providing an accurate list of sites encountered by a typical user.

Studied sites were chosen by screening the first 30 sites retrieved under each keyword. We excluded mailing lists, bulletin boards, discussion groups, sites charging fees for service or in a language other than English, and sites explicitly stating health care professionals or students as their target audience.

\section{Site evaluation}

Site evaluation was divided into: readability, quality and technical.

Readability: We used the Flesch-Kincaid Grade Level score to assess readability, as previously described ${ }^{(2)}$. A score of 8.0 or less is the recommended level for standard documents $^{(6)}$.

Quality: We used a modified score system based on previous publications and on the Health on the Net Foundation code principles ${ }^{(7-11)}$, adapted to this specific disease. Sites were scored on the following: ownership (statement of provider, or any form of support), purpose (education, profits), authorship (author's name), author qualification, attribution (references and sources citation), interactivity, and currency (first posting date and subsequent revision dates). Each of these characteristics were further divided into other subheadings (Table 1), which then received a score of 0,1 , or 2 , depending on the amount of information provided, for a total score of 13.

Technical: Background information about floaters and light flashes: definition, causes, epidemiology, diagnosis, treatment, and prognosis were evaluated in each site and a score of 0,1 , or 2 was assigned depending on the amount of information provided, for a total score of 12 (Table 2).

Websites were classified into 3 groups: academic, organizational, and commercial ${ }^{(9)}$. Commercial sites were defined as sites with commercial sponsorship such as health care professionals or clinics. Organizational sites were defined as those with no purpose of profit and belonging to an association to disseminate proper information to patients. Academic sites were defined as those providing information with or without an educational institution affiliation and not for purposes of profit.

\section{Statistical analysis}

An overall score (general quality + technical) was created for each site. All scores (general quality, technical, and overall) were converted to a percentage value of the maximum range in each category. Based on the overall percentage score, a label was assigned, as described previously ${ }^{(9)}$ : excellent $(=80 \%)$, very good ( 70 to $79 \%)$, good (60 to $69 \%$ ), fair (50 to $59 \%)$, and poor $(=49 \%)$.

One-way ANOVA was used to compare percentage scores and post-hoc analyses were performed using Tukey's pairwise comparisons. Kruskall-Wallis test was used to compare reading level among the website groups. Spearman correlation was used to analyze readability, technical, and quality scores. $\mathrm{P}<0.05$ was considered significant.

\begin{tabular}{|c|c|}
\hline \multicolumn{2}{|l|}{ Criteria score } \\
\hline \multicolumn{2}{|l|}{ 1- Ownership } \\
\hline No indication of ownership/sponsorship & 0 \\
\hline Ownership/sponsorship clearly stated & 1 \\
\hline \multicolumn{2}{|l|}{ 2- Purpose grading } \\
\hline No statement of purpose & 0 \\
\hline $\begin{array}{l}\text { Purpose stated as educational but the financial } \\
\text { profit from use of the site exists }\end{array}$ & 1 \\
\hline $\begin{array}{l}\text { Distinction is made as to whether the information provided } \\
\text { is for commercial purposes or educational purposes, or both }\end{array}$ & 2 \\
\hline \multicolumn{2}{|l|}{ 3- Authorship } \\
\hline No indication of authorship & 0 \\
\hline All other indications of authorship & 1 \\
\hline Name of person(s) supplying information clearly provided & 2 \\
\hline \multicolumn{2}{|l|}{ 4- Author qualification grading } \\
\hline $\begin{array}{l}\text { Author has no officially recognized experience } \\
\text { in the field or no such information is provided }\end{array}$ & 0 \\
\hline $\begin{array}{l}\text { Information about the author's professional qualification is } \\
\text { vague, or if the author has no professional experience but } \\
\text { has direct personal experience }\end{array}$ & 1 \\
\hline If author is a healthcare professional & 2 \\
\hline \multicolumn{2}{|l|}{ 5- Attribution } \\
\hline No references provided for requiring statements & 0 \\
\hline $\begin{array}{l}\text { References are provided for some, but not all } \\
\text { statements requiring factual information }\end{array}$ & 1 \\
\hline $\begin{array}{l}\text { Attribution for all statements conveying factual } \\
\text { information is present }\end{array}$ & 2 \\
\hline \multicolumn{2}{|l|}{ 6- Interactivity } \\
\hline No contact provided & 0 \\
\hline Telephone number, e-mail, or mailing address provided & 1 \\
\hline $\begin{array}{l}\text { Clear invitation to comment or ask questions } \\
\text { by an e-mail address or link to a form }\end{array}$ & 2 \\
\hline \multicolumn{2}{|l|}{ 7- Currency } \\
\hline No date provided & 0 \\
\hline $\begin{array}{l}\text { Date of original posting provided, but no information } \\
\text { about the date of last revisal or frequency of updates }\end{array}$ & 1 \\
\hline $\begin{array}{l}\text { Date of original posting and date of last revisal or } \\
\text { frequency of updates clearly stated }\end{array}$ & 2 \\
\hline
\end{tabular}




\section{RESULTS}

For each heading search, a range of 72 to 767,048 websites was listed. The first 30 sites were reviewed (180 sites), but because the searches discovered sometimes the same websites, only 145 unique sites were retrieved. A total of 96 $(66.2 \%)$ sites were excluded because their information: 1) was not related to floaters/light flashes (89 web sites), 2) was aimed at healthcare professionals (2 sites), 3) was limited to links to other sites (4 sites), 4) was limited to a discussion forum ( 1 site). Of the 49 included sites, 4 (8.2\%) were classified as academic, 9 (18.4\%) as organizational, and $36(73.4 \%)$ as commercial.

The mean overall percentage score was $51.5 \%( \pm 17.9)$. The mean quality percentage score was $43.6 \%( \pm 19.9)$ and the mean technical percentage score was $60 \%( \pm 24.6)$. A significant difference among the 3 groups of websites regarding general quality scores was identified (ANOVA, $\mathrm{P}=0.018$ ). Post-hoc analysis identified that commercial websites achieved statistically significant lower scores $(38.9 \% \pm 19.4)$ when compared to organizational ones $(57.2 \% \pm 24.3)$ but no dif-

\begin{tabular}{|l|}
\hline \multicolumn{1}{|c|}{ Table 2. Technical component score system } \\
Criteria \\
Definition of floaters/light flashes \\
Causes \\
Epidemiology \\
How to diagnosis \\
Treatment \\
Prognosis \\
Score \\
$0=$ not discussed on the site \\
$1=$ briefly explained on the site \\
$2=$ comprehensively explained on the site \\
\hline
\end{tabular}

ference was detected when compared to academic sites (55.8 \pm 14.6). Academic websites presented a tendency to higher scores in technical evaluation $(85.4 \% \pm 17.2)$ when compared to organizational $(65.7 \% \pm 25.5)$ and commercial ones $(55.8 \%$ \pm 23.7 ), however the difference was not significant (ANOVA, $\mathrm{P}=0.052$ ). The proportion of each grading per criteria is presented in table 3.

According to the overall percentage score, 5 sites $(10.2 \%)$ were considered excellent, $3(6.1 \%)$ very good, $7(14.3 \%)$ good, $7(14.3 \%)$ fair, and $27(55.1 \%)$ were poor. The rankings for websites according to the overall score in each of the three categories are provided in table 4.

Clarity of the text was considerably variable between sites and most sites required a high "reading level". The average Flesch-Kincaid grade level was 9.9 (i.e. suitable for $9^{\text {th }}$ grade, nineth month) with a standard deviation of \pm 2.1 . No difference among academic, organizational and commercial sites was detected (Kruskal-Wallis, $\mathrm{P}=0.325$ )

Quality scores were not correlated with technical score $(\mathrm{r}=0.23, \mathrm{p}=0.11)$. There was no correlation between quality scores and readability level $(\mathrm{r}=0.11, \mathrm{p}=0.42)$. Technical score was also not correlated to Flesch-Kincaid grade level $(\mathrm{r}=0.01$, $\mathrm{p}=0.93$ ).

\section{DISCUSSION}

We applied an objective evaluation tool for the quality of floaters/light flashes information on the Internet. Overall, the majority of floaters/light flashes information on the Internet was of poor or fair quality (69.4\%). Similar results have been reported for websites addressing other diseases ${ }^{(2,7,12-16)}$.

A common flaw of the analyzed sites was the inadequate evidence of currency (73.5\%), attribution (89.8\%) and authorship $(63.3 \%)$. These are important principles to ensure quality and reliability of site content ${ }^{(15,17)}$.

\begin{tabular}{|c|c|c|c|c|c|c|c|c|c|c|c|c|}
\hline \multirow[b]{2}{*}{ Quality } & \multicolumn{3}{|c|}{ All sites (49) } & \multicolumn{3}{|c|}{ Academic (4) } & \multicolumn{3}{|c|}{ Organizational (9) } & \multicolumn{3}{|c|}{ Commercial (36) } \\
\hline & 2 & 1 & 0 & 2 & 1 & 0 & 2 & 1 & 0 & 2 & 1 & 0 \\
\hline Ownership & 0 & 100 & 0 & 0 & 100 & 0 & 0 & 100 & 0 & 0 & 100 & 0 \\
\hline Purpose & 40.8 & 59.2 & 0 & 100 & 0 & 0 & 100 & 0 & 0 & 19.4 & 80.5 & 0 \\
\hline Authorship & 22.4 & 14.3 & 63.3 & 25 & 25 & 50 & 22.2 & 11.1 & 66.6 & 22.2 & 13.9 & 63.9 \\
\hline Author qualification & 34.7 & 0 & 65.3 & 50 & 0 & 50 & 33.3 & 0 & 66.6 & 33.3 & 0 & 66.6 \\
\hline Attribution & 4.1 & 6.1 & 89.8 & 0 & 0 & 100 & 22.2 & 11.1 & 66.6 & 0 & 5.5 & 94.4 \\
\hline Interactivity & 36.7 & 63.3 & 0 & 0 & 100 & 0 & 55.5 & 44.4 & 0 & 36.1 & 63.9 & 0 \\
\hline Currency & 20.4 & 6.1 & 73.5 & 75 & 0 & 25 & 44.4 & 22.2 & 33.3 & 8.3 & 2.8 & 88.9 \\
\hline Technical & 2 & 1 & 0 & 2 & 1 & 0 & 2 & 1 & 0 & 2 & 1 & 0 \\
\hline Definition & 77.5 & 22.4 & 0 & 100 & 0 & 0 & 100 & 0 & 0 & 69.4 & 30.5 & 0 \\
\hline Causes & 71.4 & 22.4 & 0 & 100 & 0 & 0 & 77.8 & 22.2 & 0 & 66.7 & 25 & 8.3 \\
\hline Epidemiology & 30.6 & 51 & 18.4 & 100 & 0 & 0 & 44.4 & 22.2 & 33.3 & 19.4 & 63.9 & 16.7 \\
\hline Diagnosis & 28.6 & 36.7 & 34.7 & 50 & 25 & 25 & 22.2 & 44.4 & 33.3 & 27.8 & 36.1 & 36.1 \\
\hline Treatment & 28.6 & 32.6 & 38.8 & 50 & 25 & 25 & 33.3 & 33.3 & 33.3 & 25 & 33.3 & 41.7 \\
\hline Prognosis & 26.5 & 28.6 & 44.9 & 75 & 25 & 0 & 44.4 & 22.2 & 33.3 & 16.7 & 30.5 & 52.8 \\
\hline
\end{tabular}




$\begin{aligned} & \text { Table 4. Relative ranking of the three categories of floaters/light flashes websites according to the overall (general quality and technical infor- } \\
& \text { mation) scores }\end{aligned}$
\begin{tabular}{lccc} 
Academic (4) - Rank (\%) & Organizational (9) - Rank (\%) & Commercial (36) - Rank (\%) \\
Excellent $=80$ & 25 & 22.2 & 5.6 \\
Very good= $70-79$ & 25 & 0 & 5.6 \\
Good $=60-69$ & 50 & 22.2 & 8.3 \\
Fair $=50-59$ & 0 & 22.2 & 13.9 \\
Poor $=50$ & 0 & 33.3 & 66.6 \\
\hline
\end{tabular}

Technical scores revealed that disease prognosis was frequently not addressed in the studied sites (44.9\%). We consider that mentioning the prognosis of the disease helps patients to understand that a favorable outcome is probable but medical evaluation should not be postponed. Timely execution of interventions, when necessary, is crucial for a good outcome. Information should be presented at an appropriate level for the general public, written with clear and common words. Studied websites require a high reading level indicating that a significant proportion of users would not be able to benefit from provided information.

Academic websites presented a not significant tendency to higher technical scores. There was great variation in quality and content between the analyzed sites. It is important to highlight that the high reading level required in most websites level cannot be explained by the complexity of the subject itself because technical/quality scores were not correlated with the reading level.

An abundance of floaters/light flashes information is available on the Internet. It is important for ophthalmologists not only to help to develop good-quality websites but also to direct their patients to sites that provide accurate information.

Our results reinforce the previous suggestion ${ }^{(2)}$ of preparing and providing a list of "approved" sites for patients, or a list of "tips" on how to evaluate the general quality of a site (e.g. currency, authorship). Discussing how to assess the quality of online information during medical visits can also maximize your patient benefits.

\section{RESUMO}

Objetivos: Fotopsias e miopsias são geralmente causadas pelo descolamento do vítreo posterior, mas podem estar associadas a doenças oculares. A prevenção de seqüelas importantes requer o exame rápido e apropriado do paciente. Portanto, o conhecimento pelo paciente é crucial. Este estudo objetivou avaliar a qualidade da informação sobre miopsias e fotopsias disponíveis para acesso dos pacientes na Internet. Métodos: Estudo de corte transversal. Em julho de 2005, avaliamos as informações disponíveis na Internet sobre miopsias e fotopsias, usando duas ferramentas de busca (MSN e MetaCrawler) e três palavras-chave ("floaters", "dark spots eye", "light flashes eye"). A qualidade de cada site foi avaliada por uma escala de pontos. Os sites foram classificados como acadêmicos, organizacionais ou comerciais. Avaliamos a confiabilidade, a qualidade do site (baseada no autor, propósito, qualificação do autor, interatividade, atualizações) e qualidade do conteúdo (definição, causas, epidemiologia, diagnóstico, tratamento e prognóstico). Resultados: Dos 145 sites avaliados, 49 foram incluídos no estudo. Quatro sites $(8,2 \%)$ foram acadêmicos, $9(18,4 \%)$ organizacionais e 36 $(73,4 \%)$ foram comerciais. Em sua grande maioria $(53 \%)$, as informações contidas nos sites foram consideradas como pobres e a qualidade não estava correlacionada com a classificação do site. Conclusão: As informações disponíveis na Internet sobre miopsias e fotopsias são insuficientes.

Descritores: Descolamento do vítreo/etiologia; Transtornos da visão/etiologia; Internet, sistemas de informação; Educação do paciente

\section{REFERENCES}

1. Dornan BA, Oermann MH. Evaluation of breastfeeding websites for patient education. MCN Am J Matern Child Nurs. 2006;31(1):18-23

2. Martins EN, Morse LS. Evaluation of internet websites about retinopathy of prematurity patient education. Br J Ophthalmol. 2005;89(5):565-8.

3. Sutherland LA, Wildemuth B, Campbell MK, Haines PS. Unraveling the web: an evaluation of the content quality, usability, and readability of nutrition websites. J Nutr Educ Behav. 2005;37(6):300-5.

4. Summers AL, Logsdon MC. Websites for postpartum depression: convenient, frustrating, incomplete, and misleading. MCN Am J Matern Child Nurs. 2005; 30(2):88-94; quiz 95-6.

5. Margo CE, Harman LE. Posterior vitreous detachment. How to approach sudden-onset floaters and flashing lights. Postgrad Med. 2005;117(3):37-42.

6. Ohio State Revising and editing with word: Spelling, grammar, and style. Available at http://ccl.english.ohiostate.edu/handouts/miscellaneous/ word_revision_spelling_grammar_pc.htm. Accessed April 12, 2004.

7. Sandvik H. Health information and interaction on the internet: a survey of female urinary incontinence. BMJ. 1999;319(7201):29-32.

8. Butler L, Foster NE. Back pain online: a cross-sectional survey of the quality of web-based information on low back pain. Spine. 2003;28(4):395-401.

9. Bohacek L, Gomez M, Fish JS. An evaluation of internet sites for burn scar management. J Burn Care Rehabil. 2003;24(4):246-51; discussion 245.

10. Silberg WM, Lundberg GD, Musacchio RA. Assessing, controlling, and assuring the quality of medical information on the Internet: Caveant lector et viewor-Let the reader and viewer beware. JAMA. 1997;277(15):1244-5. Comment in: JAMA. 1997;278(8):632; author reply 632-3.

11. Health on the Net Foundation. HON code of conduct for medical and health websites [homepage on the Internet]. Version 1.6 April 1997. [updated 2007 Mar 20 ] [cited 2004 April 12]. Available from: www.hon.ch/HONcode/ Conduct.html.

12. Oermann MH, Lowery NF, Thornley J. Evaluation of websites on management of pain in children. Pain Manag Nurs. 2003;4(3):99-105.

13. Murphy R, Frost S, Webster P, Schmidt U. An evaluation of web-based information. Int J Eat Disord. 2004;35(2):145-54. 
14. Croft DR, Peterson MW. An evaluation of the quality and contents of asthma education on the World Wide Web. Chest. 2002; 121(4):1301-7. Comment in: Chest. 2002;121(4):1015-6.

15. Reed M, Anderson C. Evaluation of patient information Internet websites about menopause and hormone replacement therapy. Maturitas. 2002;43(2): 135-54.
16. Kisely S, Ong G, Takyar A. A survey of the quality of web based information on the treatment of schizophrenia and Attention Deficit Hyperactivity Disorder. Aust N Z J Psychiatry. 2003;37(1):85-91.

17. Kim P, Eng TR, Deering MJ, Maxfield A. Published criteria for evaluating health related websites: review. BMJ. 1999;318(7184):647-9. 